\title{
Journal of Biochemical \& Microbial Technology
}

\section{Oxygen transfer rate modulates the dextransucrase production by Acetobacter tropicalis}

\author{
Chauhan $\mathrm{S}^{1}$, Nisha ${ }^{1}$ and Azmi $\mathrm{W}^{1, *}$ \\ ${ }^{1}$ Department of Biotechnology, Himachal Pradesh University, Shimla, Himachal Pradesh, 171005, India
}

\begin{abstract}
Dextransucrase is an important class of extracellular enzymes with great industrial importance. Dextransucrase synthesizes the high molecular weight glucose polymer dextran by transferring D-glucosyl moieties to a growing glucan chain. Keeping in view the potential of dextransucrase, bench scale production of Acetobacter tropicalis cells with high dextransucrase activity was carried out in laboratory fermenter at $7 \mathrm{~L}$ scale. The growth of $A$. tropicalis has been affected by the supply of oxygen during the fermentation. Therefore, the optimum combination of aeration rate and agitation speed for dextransucrase production from A. tropicalis was found to be $0.5 \mathrm{vvm}$ and $450 \mathrm{rpm}$. The volumetric oxygen transfer coefficient, $\mathrm{K}_{\mathrm{L}} a$ values were found to affect the growth of $A$. tropicalis and production of dextransucrase. In the present study, the growth and dextransucrase production increased with increase in $\mathrm{K}_{\mathrm{L}} a$ upto an optimum limit and then started decreasing with increase in $\mathrm{K}_{\mathrm{L}} a$. Maximum biomass $(1.41 \mathrm{mg} / \mathrm{ml})$ and maximum dextransucrase activity (15.8 U/ml) was obtained at $\mathrm{K}_{\mathrm{L}} a$ value of $0.28 \mathrm{~min}^{-1}$. The maximum dextransucrase activity obtained in laboratory fermenter was $15.8 \mathrm{U} / \mathrm{ml}$ which was greater than the enzyme level obtained at shake flask level $(11.6 \mathrm{U} / \mathrm{ml})$.
\end{abstract}

Keywords: dextransucrase; Acetobacter tropicalis; dextran; fermentation; agitation; aeration; dissolved oxygen; dissolved oxygen concentration $\left(\mathrm{C}_{\mathrm{L}}\right)$; volumetric oxygen transfer coefficient $\left(\mathrm{K}_{\mathrm{L}} a\right)$.

\section{Introduction}

Dextransucrase (sucrose: 1,6- $\alpha$-D-glucan 6- $\alpha$-glucosyltransferase, EC 2.4.1.5) is the enzyme that catalyzes the synthesis of dextran from sucrose. Dextran (C6H1005) $\mathrm{n}$ is a polysaccharide consisting of glucose monomers linked mainly by $\alpha(1 \rightarrow 6)$ glycosidic linkages in the linear chain $(95 \%)$ and $5 \% \alpha(1 \rightarrow 2), \alpha(1 \rightarrow 3)$ and/or $\alpha(1 \rightarrow 4)$ branch linkages [1, 2]. Dextransucrase synthesizes dextran by transferring D-glucosyl moieties to a growing glucan chain. Dextransucrase is an important class of extracellular enzymes with great industrial importance and the Leuconostoc mesenteroides NRRL B-512F dextransucrase has been used to produce commercial dextran [3]. Dextransucrase was produced mainly by various Leuconostoc and Streptococcus species $[4,5]$ and by the mold Rhizopus spp. [6]. Dextransucrase was also found to be secreted by Lactobacillus, Acetobacter and Pediococcus pentosaceus [7].

Dextrans are useful in various industries because of their inertness, porous structure and gelling properties [8]. Moreover, the presence of $95 \%$ linear linkages makes dextran water soluble. Dextrans have been used as food syrup stabilizers, matrix of chromatography columns, blood plasma substitutes, antithrombogenic agents, treatment for iron deficiency anaemia, drug carriers [9, 8]. Dextransucrase also catalyzes the transfer of glucosyl units from sucrose into acceptor molecules. This results in the synthesis of glucooligosaccharides $[10,11]$ and the release of fructose. Fructose $\left(\mathrm{C}_{6} \mathrm{H}_{12} \mathrm{O}_{6}\right)$ is a low caloric sugar and has extensively been used in food industry. It was possible to synthesize oligosaccharides with $\alpha$ $(1 \rightarrow 2)$ branch linkage with this enzyme $[12,13]$. These molecules are highly resistant to the attack of digestive enzymes and have also been proven to stimulate the growth of beneficial bacteria of the intestinal microflora $[14,15]$. Dextransucrase can also be used to catalyze many oligosaccharides [16] and other useful carbohydrates such as the antioxidant 1,5-anhydro-D-fructose [17].

*Corresponding author: Azmi W, Department of Biotechnology, Himachal Pradesh University, Shimla, Himachal Pradesh, 171005, India, Tel.: +91 177 2831948; Email: wamikazmi@yahoo.com

Received 12 April 2013 Revised 15 June 2013 Accepted 22 June 2013 Published 28 June 2013

Citation: Chauhan S, Nisha, Azmi W (2013) Oxygen transfer rate modulates the dextransucrase production by Acetobacter tropicalis. J Biochem Microb Technol 1:1-7. JBMT13-10003

Copyright: (C) 2013 Chauhan S, et al. This is an open-access article distributed under the terms of the Creative Commons Attribution License, which permits unrestricted use, distribution and reproduction in any medium, provided the original author and source are credited. 
In batch fermentation with Leuconostoc mesenteroides NRRL-B512(F), decrease in nitrogen/carbon ratio slows down the rate of dextransucrase production (18). Temperature, $\mathrm{pH}$ and sucrose concentration highly affects the production of dextransucrase by L. mesenteroides NRRL-B512(F) [19, 20]. High sucrose concentration does not inhibit the cell growth, however at concentration higher than $40 \mathrm{~g} / \mathrm{dm}^{3}$ separation of products from cells become difficult. The dextran and fructose mixture obtained by fermentation of sucrose rich media by $L$. mesenteroides NRRL-B512(F) were separated by using simulated moving bed (SMB) chromatography [21].

The volumetric oxygen transfer coefficient $\left(\mathrm{K}_{\mathrm{L}} a\right)$ was considered as one of the most important scale up factors in fermentations. The dissolved oxygen (DO) concentration in a fermentation broth has a profound effect on the performance of aerobic fermentation systems. Schneider et al, [22] reported the highest yield under an aeration of $1 \mathrm{vvm}$ where the oxygen level was stayed between 40-80 $\%$ of saturation during the fermentation. Lazic et al. [23] found that $\mathrm{pH} 5.5$ and $0.05 \mathrm{vvm}$ of air, was most favourable conditions for dextran production by Leuconostoc mesenteroides and it also reduced the fermentation time. The aim of this study was to optimize the effect of agitation speed and aeration rate on dextransucrase production by Acetobacter tropicalis and to determine the role of oxygen transfer rate on the enzyme production.

\section{Materials and methods}

\section{Chemicals}

All the chemicals used in the present study were either procured from Sigma Aldrich (U.S.A.) or HiMedia Laboratories Pvt. Ltd., Mumbai and were of high purity analytical grade. The media constituents were of bacteriological grade.

\section{Microorganism and maintenance of culture}

Acetobacter tropicalis was procured from the Department of Biotechnology, Himachal Pradesh University, Shimla. A. tropicalis was maintained on modified MRS (Mann Rogosa Sharpe's) [24] agar plates and agar slants having the following composition (\%, w/v): Sucrose 2.0, peptone 1.0, $\mathrm{MnSO}_{4} 0.025$, Sodium Acetate 0.5 and agar $2.0 \mathrm{pH}$ 7.0 ) or in $20 \%$ (v/v) glycerol stocks and subculturing was done periodically after 3 days with the same medium at $25^{\circ} \mathrm{C}$.

\section{Inoculum and medium preparation for bench}

\section{scale fermentation}

The optimum conditions for production and effect of oxygen transfer rate on cell mass and dextransucrase activity by fermentation at a scale of $7 \mathrm{~L}$ were investigated for $A$. tropicalis. The medium components and different physical parameters were optimized in shake flask level and the optimized parameters were used for bench scale fermentation (data not shown). For the development of a laboratory inoculum, the seed was prepared in conical flasks containing the seed medium $(\%, \mathrm{w} / \mathrm{v}$; Sucrose 2.0, peptone 1.0, $\mathrm{MnSO}_{4}$ 0.025, Sodium Acetate 0.5; $\mathrm{pH}$ 7.0). The seed medium was inoculated with organism A. tropicalis, and incubated at $25^{\circ} \mathrm{C}$ for $12 \mathrm{~h}$ on a rotary shaker $(150 \mathrm{rpm})$. The production medium $(\mathrm{pH} 7.0)$ contained (\%,w/v) Sucrose 2.0, peptone 1.0, $\mathrm{MnSO}_{4}$ 0.025 , Sodium Acetate 0.5. The fermenter was loaded with production medium with additionally contained $0.01 \%(\mathrm{v} / \mathrm{v})$ silicone oil as antifoam agent (Himedia). The medium was sterilized in situ with the help of steam supplied through the jacket of fermenter.

\section{Dextransucrase assay}

Dextransucrase converts sucrose into dextran and D-fructose. Dextransucrase activity was determined spectrophotometrically by measuring the reducing sugar released from sucrose (Miller, 1959) [25]. The dextransucrase from $A$. tropicalis was found to be extracellular in nature and hence the supernatant was used for the enzyme assay. The assay mixture $(2 \mathrm{ml})$ contained enzyme solution $(10 \mu \mathrm{L})$ and $2 \%$ sucrose $(2.0$ $\mathrm{ml})$ prepared in acetate buffer (25 mM, pH 5.5). The reaction mixture was incubated at $37^{\circ} \mathrm{C}$ for $30 \mathrm{~min}$. The reaction was stopped by keeping the reaction mixture in boiling water bath $\left(100^{\circ} \mathrm{C}\right)$ for $10 \mathrm{~min}$. A set of control was also run. From the reaction mixture, $1 \mathrm{~mL}$ was discarded and $1 \mathrm{ml}$ DNSA (dinitosalacylic acid) reagent was added to remaining $1 \mathrm{ml}$ reaction mixture. . The reaction mixture was kept in boiling waterbath for $20 \mathrm{~min}$ for colour development (Yellow to Red colouration). The absorbance of colour developed was measured at 540 $\mathrm{nm}$ in a spectrophotometer (LABINDIA). Activity of the dextransucrase from the supernatant of $A$. tropicalis was expressed in terms of units $(\mathrm{U} / \mathrm{ml})$. The dextransucraes unit has been defined as the amount of enzyme that liberates $1 \mu \mathrm{mol}$ of reducing sugar (fructose) per min per $\mathrm{ml}$ at $37^{\circ} \mathrm{C}$ under standard assay condition.

\section{Sterilization and inoculation of production medium}

The fermentation was carried out in $14 \mathrm{~L}$ laboratory fermenter (BIOFERM-LS2, Scigenics India Pvt. Ltd.) at 7 $\mathrm{L}$ working volume in batch mode. As the fermenter has inbuilt facility of sterilization (in situ sterilizable), $7 \mathrm{~L}$ production medium $[(\%, \mathrm{w} / \mathrm{v})$ Sucrose 2.0, peptone 1.0, $\mathrm{MnSO}_{4}$ 0.025, Sodium Acetate 0.5.] was loaded into the fermenter. The sterilization of the production medium was carried out at $121^{\circ} \mathrm{C}$ for $15 \mathrm{~min}$. After the completion of sterilization cycle, the temperature of the medium was adjusted to $25^{\circ} \mathrm{C}$ by cooling. The sterilized production medium was inoculated with $1 \%(\mathrm{v} / \mathrm{v}), 12 \mathrm{~h}$ old seed culture through the inoculation port by peristaltic pump attached to a feed bottle. The $\mathrm{pH}$, temperature and dissolved oxygen were monitored throughout the operation. However, temperature was maintained at $25^{\circ} \mathrm{C}$ for the entire course of fermentation with the help of inbuilt heater and chiller. After inoculation, periodical sampling (at $1 \mathrm{~h}$ interval) was carried out and samples were analyzed for growth and dextransucrase production by $A$. tropicalis cells. 


\section{Growth and production of dextransucrase}

The growth of $A$. tropicalis cells and activity of dextransucrase was measured under different conditions of agitation and aeration by adopting the analytical procedures. The effect of these variables on $\mathrm{pH}$, dissolved oxygen (DO, \% saturation), cell mass and dextransucrase activity was observed.

Effect of agitation on the growth and production of dextransucrase activity by Acetobacter tropicalis

Agitation rate is important for maintaining homogeneity in bioreactor and also helps in oxygen transfer. The effects of agitation on production of biomass, dextransucrase activity, DO and $\mathrm{pH}$ by $A$. tropicalis was investigated by varying the agitation rate (150, 300, 450 and $600 \mathrm{rpm})$. The fermentation was carried out at $250 \mathrm{C}$ temperature keeping the aeration rate $0.5 \mathrm{vvm}$. Samples at regular interval of $1 \mathrm{~h}$ were withdrawn and analyzed for cell growth and dextransucrase activity. The $\mathrm{pH}$ and DO of the fermentation broth during the entire course of cultivation were monitored with the help of DO and pH probe. The suitability of the agitation rate was determined on the basis of the results obtained.

Effect of aeration rate on growth and production of dextransucrase activity by Acetobacter tropicalis

The effect of aeration rate on the growth and production of dextransucrase by $A$. tropicalis and change in $\mathrm{pH}$ and dissolved oxygen (DO) profile of the fermentation broth was investigated under varying aeration rate 0.50 and $1.00 \mathrm{vvm}$ ) at 300 and $450 \mathrm{rpm}$.

\section{Determination of volumetric oxygen transfer}

coefficient $\left(K_{L} a\right)$

Dissolved oxygen concentration depends on the relative rate of oxygen transfer and utilization.

Rate of oxygen transfer $\left(\mathrm{nO}_{2}, \mathrm{~T}\right)$ is given by following equation:

$\mathrm{nO}_{2}, \mathrm{~T}=\mathrm{K}_{\mathrm{L}} a\left(\mathrm{C}_{-}^{*} \mathrm{C}_{\mathrm{L}}\right)$ Equation 1

The volumetric oxygen transfer coefficient $\left(\mathrm{K}_{\mathrm{L}} a\right)$ is defined by following equation:

$\mathrm{K}_{\mathrm{L}} a=\mathrm{n}_{02}, \mathrm{~T} / \mathrm{C}_{-}^{*} \mathrm{CL}$ Equation 2

Dynamic method or gassing out method for $\mathrm{K}_{\mathrm{L}} a$ determination was used which is based upon the dynamic oxygen balance equation:

$\mathrm{dCL} / \mathrm{dt}=\mathrm{K}_{\mathrm{L}} a\left(\mathrm{C} *_{-} \mathrm{CL}\right)-\mathrm{Q}_{02} \mathrm{X}$ Equation 3

$\mathrm{K}_{\mathrm{L}} a=$ Volumetric oxygen transfer coefficient

$\mathrm{C} * \& \mathrm{C}_{\mathrm{L}}=$ Saturation and actual dissolved oxygen concentration in the liquid medium, respectively.

$\mathrm{Q}_{\mathrm{o} 2}=$ Rate of oxygen consumption per unit mass of cells (cellular respiration) (mM02 $\mathrm{g}^{-1} \mathrm{~h}^{-1}$ )

Rearranging the equation 3 :

$\mathrm{CL}=\mathrm{C} *-1 / \mathrm{K}_{\mathrm{L}} a\left(\mathrm{Q}_{02} \mathrm{X}+\mathrm{dCL} / \mathrm{dt}\right)$------ Equation 4
For this, when fermentation was in active respiration, aeration was stopped temporally and decrease in dissolved oxygen concentration $\left(\mathrm{C}_{\mathrm{L}}\right)$ was measured as a function of time for determination of oxygen uptake rate $\left(\mathrm{Q}_{02} \mathrm{X}\right)$. Aeration was established and increase in the dissolved oxygen concentration was also measured as a function of time. Punctual differential was obtained from gassing curve and $\mathrm{C}_{\mathrm{L}}$ vs. $\mathrm{dC}_{\mathrm{L}} / \mathrm{dt}+\mathrm{Q}_{\mathrm{O} 2} \mathrm{X}$ were correlated.

\section{Role of $K_{L}$ a on growth and enzyme production}

\section{by Acetobacter tropicalis}

The effect of $\mathrm{K}_{\mathrm{L}} a$ was determined by comparing the $\mathrm{K}_{\mathrm{L}} a$ values of different fermentation batches of $A$. tropicalis with respect to the biomass and dextransucrase production. The results were demonstrated by $\mathrm{K}_{\mathrm{L}} a$ versus growth and enzyme activity curve.

\section{Results and discussion}

Effect of agitation and aeration rate on the growth and dextransucrase production by Acetobacter tropicalis

The fermentation was carried out at controlled temperature of $25^{\circ} \mathrm{C}$ with optimized medium ( $\mathrm{pH} 7.0$ ) containing (\%, w/v) Sucrose 2.0, Peptone 1.0, $\mathrm{MnSO}_{4}$ 0.025 , Sodium acetate 0.5 at $0.5 \mathrm{vvm}$ aeration rate but at different agitation speed (150, 300, 450 and $600 \mathrm{rpm})$. The effect of varying agitation rate was studied on production of dextransucrase in the cells of Acetobacter tropicalis. The agitation improves the rate of oxygen transfer from bulk gas to the medium, which has ultimately been utilized by the growing microorganism. The increase in the agitation speed from $150 \mathrm{rpm}$ to $450 \mathrm{rpm}$ proved to be beneficial for the growth of the $A$. tropicalis (Figure $1 \mathrm{a}$ ). The maximum cell mass $(1.41 \mathrm{mg} / \mathrm{ml})$ of $A$. tropicalis was obtained at 7 $\mathrm{h}$ of fermentation at $450 \mathrm{rpm}$, which was higher than the cell mass attained under $300 \mathrm{rpm}$ at $8 \mathrm{~h}$ of fermentation $(1.25 \mathrm{mg} / \mathrm{ml})$. However, at $150 \mathrm{rpm}$ agitation the growth rate was much slower and this caused an early attainment of the stationary phase. Further increase in agitation rate (600 rpm) decreases the growth. This might be due to the shearing forces operative at high agitation rate. The 450 rpm of agitation speed at $0.5 \mathrm{vvm}$ aeration was found to be the most optimum for the cultivation of $A$. tropicalis. The maximum dextransucrase activity of $15.77 \mathrm{U} / \mathrm{ml}$ was obtained in $7^{\text {th }} \mathrm{h}$ at $450 \mathrm{rpm}$ agitation (Figure $1 \mathrm{~b}$ ) followed

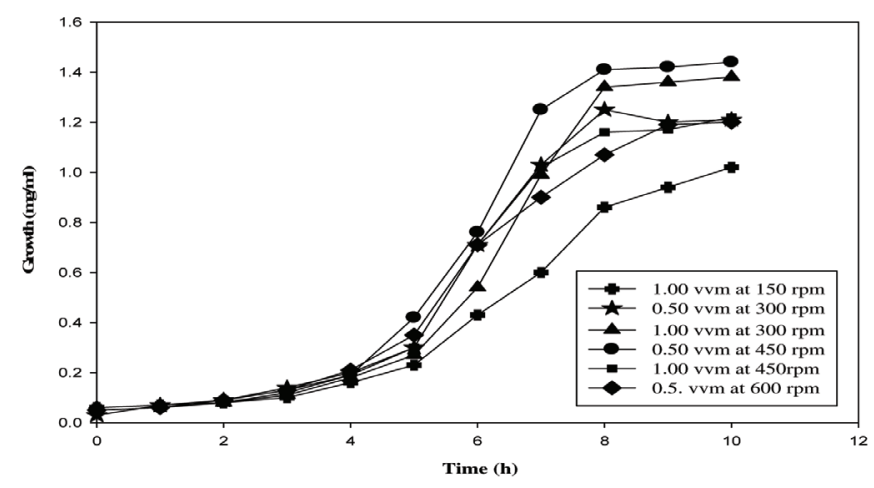

Figure 1a Effect of agitation speed and aeration rate on cell mass production by Acetobacter tropicalis in fermenter. 
by agitation rate of $300 \mathrm{rpm}$ at $8^{\text {th }} \mathrm{h}$ of fermentation $(13.35$ $\mathrm{U} / \mathrm{ml}$ ). In case of $150 \mathrm{rpm}$ and $600 \mathrm{rpm}$, the maximum dextransucrase activity was found to be $9.83 \mathrm{U} / \mathrm{ml}$ and $11.93 \mathrm{U} / \mathrm{ml}$ respectively at $8^{\text {th }} \mathrm{h}$ of fermentation.

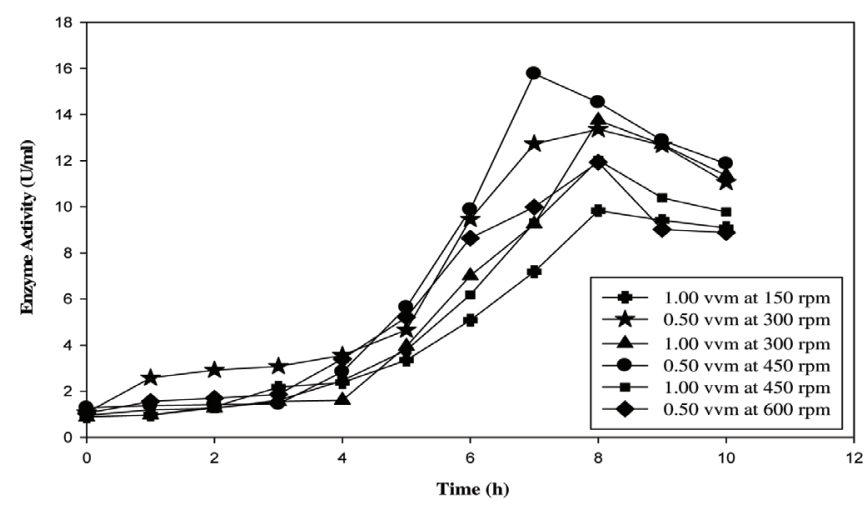

Figure 1b Effect of agitation speed and aeration rate on dextransucrase activity by Acetobacter tropicalis in fermenter.

Although the agitation has more profound effect in improving the dissolved oxygen concentration than aeration, some negative factors were also associated with the agitation speed that can hamper the net benefit an aerobe can have. An increase in the agitation rate beyond $450 \mathrm{rpm}$ proved to be ineffective in enhancing the dextransucrase production, and in fact resulted in decrease in dextransucrase activity. The dissolved oxygen profiles of the fermentation broth under different rates of agitation reveals that depletion in the dissolved oxygen was insignificant at the higher rate of agitation (Figure 1 c). In contrast to the decline in DO from $100 \%$ to $1.2 \%$ and $1.1 \%$ during first $6 \mathrm{~h}$ and $5 \mathrm{~h}$ of the course of fermentation at $150 \mathrm{rpm}$ and $300 \mathrm{rpm}$ respectively, the DO level at higher agitation rate (450 rpm) first dropped below 1.2\% during first $6 \mathrm{~h}$ and then started to increase from $8 \mathrm{~h}$ and reached to $20 \%$ at $10^{\text {th }} \mathrm{h}$ of fermentation. Further increase in agitation speed $(600 \mathrm{rpm})$ dropped the DO level to $1.3 \%$ at $6 \mathrm{~h}$ and started to increase and reached $33.7 \%$ at $10^{\text {th }} \mathrm{h}$ of fermentation.

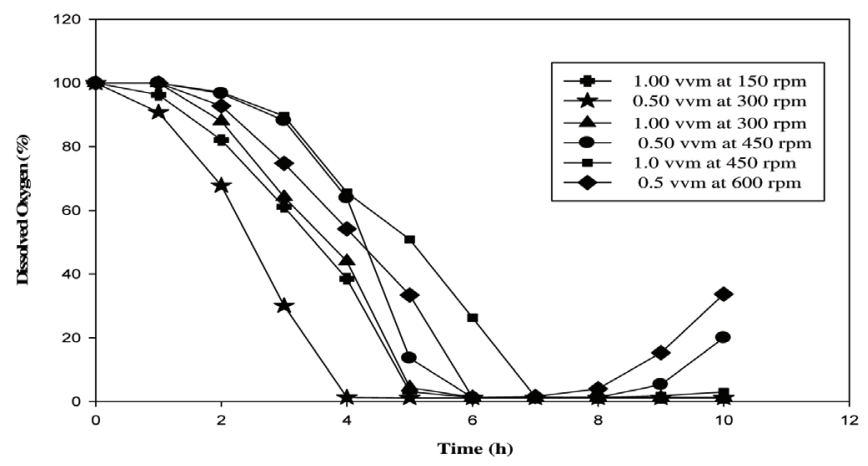

Figure 1c Effect of agitation speed and aeration rate on dissolved oxygen during growth of Acetobacter tropicalis in fermenter.

The $\mathrm{pH}$ of the fermentation broth was also found to decrease during the course of fermentation in all the cases (Figure $1 \mathrm{~d}$ ). The decrease in the $\mathrm{pH}$ of the fermentation broth was found to be associated with the growth of $A$. tropicalis. The reduction in culture broth $\mathrm{pH}$ from 7.0 to 5.0 might be due to the acid metabolite production by the utilization of carbohydrate substrate. It can be inferred from these results that rate of agitation was helpful in maintaining the higher dissolved oxygen level which subsequently help in growth and dextransucrase production by $A$. tropicalis.

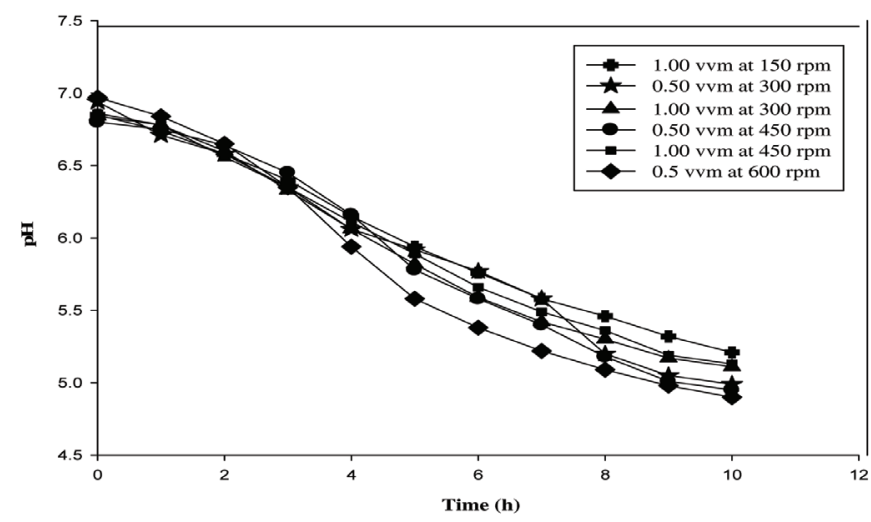

Figure 1d Effect of agitation speed and aeration rate on the final $\mathrm{pH}$ of fermentation broth during growth of Acetobacter tropicalis in fermenter.

For aerobic organisms, rate of aeration is important as it affects the metabolic and physiological process. Therefore, it was essential to find out the optimum combination of rate of aeration and agitation speed for the production of dextransucrase by $A$. tropicalis. Hence these cells were grown at varying aeration rate $(0.5 \mathrm{vvm}$ and $1.0 \mathrm{vvm})$ at the agitation speed of 300 and $450 \mathrm{rpm}$. The growth of A. tropicalis was affected by the supply of oxygen during the course of fermentation. The maximum growth of $A$. tropicalis was obtained at $8^{\text {th }} \mathrm{h}$ of fermentation $(1.41 \mathrm{mg} /$ $\mathrm{ml}$ ) at $0.5 \mathrm{vvm}$ aeration rate and $450 \mathrm{rpm}$. The cell mass production increased up to $8^{\text {th }} \mathrm{h}$ of incubation and after that it became constant at $0.5 \mathrm{vvm}$ aeration as well as at 1.0 vvm (Figure $1 \mathrm{a})$. The maximum biomass $(1.34 \mathrm{mg} / \mathrm{ml})$ at $1.0 \mathrm{vvm}$ aeration rate and $300 \mathrm{rpm}$ was also obtained at $8^{\text {th }}$ $\mathrm{h}$ of fermentation and remain nearly constant with further incubation. In case of $300 \mathrm{rpm}$ agitational speed, $1.0 \mathrm{vvm}$ of aeration resulted in maximum biomass as compared to $0.5 \mathrm{vvm}(1.25 \mathrm{mg} / \mathrm{ml})$. In contrast, at $450 \mathrm{rpm}$ maximum growth yield was obtained at $0.5 \mathrm{vvm}(1.41 \mathrm{mg} / \mathrm{ml})$ as compared to $1.0 \mathrm{vvm}(1.16 \mathrm{mg} / \mathrm{ml})$. Similarly, maximum dextransucrase production $(15.77 \mathrm{U} / \mathrm{ml})$ was observed at $7^{\text {th }} \mathrm{h}$ of fermentation at $0.5 \mathrm{vvm}$ aeration and $450 \mathrm{rpm}$ followed by $13.75 \mathrm{U} / \mathrm{ml}$ at $8^{\text {th }} \mathrm{h}$ at $1.0 \mathrm{vvm}$ at $300 \mathrm{rpm}$. Further increase in aeration ( $1.0 \mathrm{vvm})$ at $450 \mathrm{rpm}$ resulted in decrease of the dextransucrase activity to $12.02 \mathrm{U} / \mathrm{ml}$. Hence it could be concluded that with increase in aeration rate, there was increase in dextransucrase activity upto optimum level and then decrease drastically with increase in further aeration (Figure $1 \mathrm{~b}$ ). Lazic et al, [23] found that pH 5.5 and 0.05 vvm of air, were the favourable conditions for dextransucrase production by Leuconostoc mesenteroides and these optimal conditions also reduced the fermentation time. High activity of dextransucrase was attained when fermentation of Leuconostoc mesenteroides FT045 B was carried out in medium containing 3 and 4\% of sucrose at $25^{\circ} \mathrm{C}, 132 \mathrm{rpm}$ and $0.15 \mathrm{vvm}$ aeration, the dextransucrase production obtained was nearly 11.0 
DSU/mL [26]. Highest dextransucrase yield was obtained under $1 \mathrm{vvm}$ aeration where the oxygen level was stayed between 40-80 \% of saturation [22] Further, Monsan et al. [27] found highest dextransucrase activity in moderate conditions of stirring and aeration.

Course of fermentation by Acetobacter tropicalis for the production of dextransucrase

During the present study, $0.5 \mathrm{vvm}$ aeration at $450 \mathrm{rpm}$ agitation speed was found to be the most optimum for the production of dextransucrase by Acetobacter tropicalis in a laboratory fermenter. The fermentation by $A$. tropicalis cells for dextransucrase production was carried out in the optimized medium (pH 7.0) at $0.5 \mathrm{vvm}$ aeration and $450 \mathrm{rpm}$ agitation speed. The cells of $A$. tropicalis started growing exponentially after an initial lag period of $3 \mathrm{~h}$. The stationary phase of growth was attained after $8 \mathrm{~h}$ of incubation. The maximum cell mass $(1.41 \mathrm{mg} / \mathrm{ml})$ of A. tropicalis was observed at $8 \mathrm{~h}$ of fermentation. The maximum enzyme activity obtained was $15.8 \mathrm{U} / \mathrm{ml}$ at $7 \mathrm{~h}$ of incubation which does not coincide with the maximum growth of $A$. tropicalis (Figure 2). The culture $\mathrm{pH}$ reduced from 7.0 to 5.0 at $10^{\text {th }} \mathrm{h}$ of growth. The increase in cell mass of $A$. tropicalis leads to the rapid utilization of oxygen which reaches to minimum at $6 \mathrm{~h}$ of fermentation. The concentration of dissolved oxygen was remained minimal till $8 \mathrm{~h}$ of incubation. Once the A. tropicalis cells reached the stationary phase, the dissolved oxygen concentration started increasing and attained 20\% saturation at $10 \mathrm{~h}$ of incubation. Landon [28] studied effect of stirring on dextransucrase production for Leuconostoc mesenteroides NRRL B512 (F) and suggested some limitations in difussion through cell membrane in static culture. Recently, dextransucrase production by a new bacterial strain Weissella confusa Cab3 was scaled up in lab scale bioreactor resulting in further enhancement of enzyme activity $(22.0 \mathrm{U} / \mathrm{ml})$ than shake flask level of $17.54 \mathrm{U} / \mathrm{ml}$ [29].The dextransucrase activities in excess of $21.9 \mathrm{U} /$ $\mathrm{ml}$ have also been obtained by culturing $L$. mesenteroides NRRL B512(F) under non-aerated fed-batch fermentation conditions [30]. However, Santos et al, [20] found that aeration does not have an important effect in fermentation by L. mesenteroides NRRL B512(F). It affects positively the strain growth but the dextransucrase activity decreased with aeration.

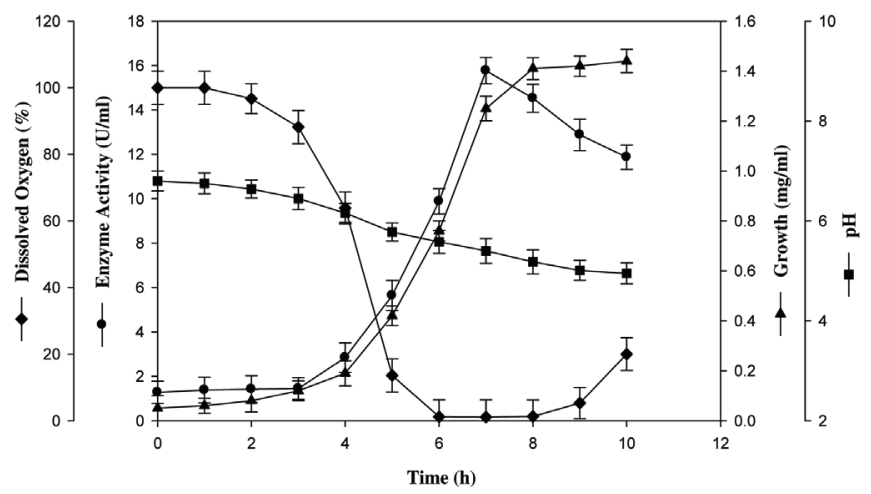

Figure 2 The course of fermention by Acetobacter tropicalis for the production of dextransucrase.

\section{Determination of volumetric oxygen} transfer coefficient $\left(K_{L} a\right)$

In many aerobic fermentation systems, the rate of oxygen transfer to the cells is the limiting factor which determines the rate of biological conversion. The volumetric oxygen transfer coefficient $\left(\mathrm{K}_{\mathrm{L}} a\right)$ is an important parameter which is used to compare the oxygen transfer capabilities of various aerobic bioreactors. Dissolved oxygen concentration depends on the relative rate of oxygen transfer and utilization. Both the agitation speed and aeration rate affect the value of $\mathrm{K}_{\mathrm{L}} a$. The DO concentration, $\mathrm{C}_{\mathrm{L}}$, has to be greater than the critical value of DO in order to avoid oxygen limitation. Aerobic biological reactors are designed to maximize the value of $\mathrm{K}_{\mathrm{L}} a$ in order to keep the value of $\mathrm{C}_{\mathrm{L}}$ above the critical level. The critical dissolved oxygen concentration is in order of $5-10 \%$ of the solubility of oxygen. The values of $\mathrm{K}_{\mathrm{L}} a$ during the cultivation of $A$. tropicalis were determined by $\mathrm{C}_{\mathrm{L}}$ versus $\mathrm{Q}_{02} \mathrm{X}+[(\mathrm{dCL} /$ $\mathrm{dt}$ )] curve (Figure 3). The maximum $\mathrm{K}_{\mathrm{L}} a, 0.38 \mathrm{~min}^{-1}$ was obtained for the fermentation batch with aeration rate of $0.5 \mathrm{vvm}$ and agitation speed of $600 \mathrm{rpm}$ whereas the minimum $\mathrm{K}_{\mathrm{L}} a, 0.11 \mathrm{~min}^{-1}$ was obtained at $0.5 \mathrm{vvm}$ and $450 \mathrm{rpm}$. The values of $\mathrm{K}_{\mathrm{L}} a$ for $1.0 \mathrm{vvm}$ at $300 \mathrm{rpm}, 0.5$ vvm at $450 \mathrm{rpm}$ and $1.0 \mathrm{vvm}$ at $600 \mathrm{rpm}$ were $0.18 \mathrm{~min}^{-1}$, $0.28 \mathrm{~min}^{-1}$ and $0.29 \mathrm{~min}^{-1}$ respectively. The fermentation kinetics of Leuconostoc mesenteroides in a $5 \mathrm{~L}$ bioreactor for the production of dextransucrase was studied and $\mathrm{K}_{\mathrm{L}} a$ obtained was $30.85 \mathrm{~h}^{-1}$ at $0.15 \mathrm{vvm}$ aeration rate and $225 \mathrm{rpm}$ [31]. In case of $ß$-glucuronidase production by recombinant E. coli, highest enzyme production was obtained at $300 \mathrm{rpm}$ agitation and $2 \mathrm{vvm}$ aeration having $\mathrm{K}_{\mathrm{L}} a$ value $1.686 \mathrm{~h}^{-1}$ [32]. The best condition obtained for pectate lyase production from Paenibacillus polymyxa N10 were $150 \mathrm{rpm}$ agitation, $0.5 \mathrm{vvm}$ aeration with $\mathrm{K}_{\mathrm{L}} a$ value $37.08 \mathrm{~h}^{-1}$ [33]. Sachidanandham et al, [34] determined $\mathrm{K}_{\mathrm{L}} a$ as a function of impeller speed and the rate of aeration, and observed an inhibitory effect on the production of protease using Bacillus amyloliquefaciens by increasing the impeller speed (thus increasing $\mathrm{K}_{\mathrm{L}} a$ ) beyond $300 \mathrm{rev}$ $\mathrm{min}^{-1}$ in a 10 litre batch bioreactor. Belo and Mota [35] reported an increase in $\mathrm{K}_{\mathrm{L}} a$ (due to an increase in impeller speed) and its negative effect on recombinant cytochrome

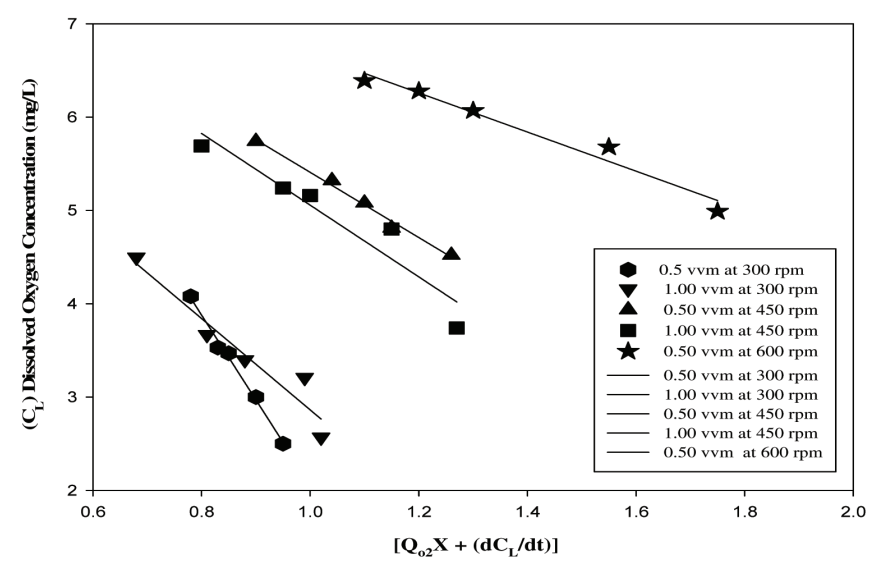

Figure $3 \mathrm{C}_{\mathrm{L}}$ versus $\mathrm{Q}_{02} \mathrm{X}+[(\mathrm{dCL} / \mathrm{dt})]$ curve for determination of volumetric oxygen transfer coefficient (KLa) of Acetobacter sp. under varying conditions of fermentation. 
b5 production in E. coli. Pham et al, [36] reported an increase in xylanase production rate with an increase in $\mathrm{K}_{\mathrm{L}} a$, but the final concentration of the enzyme was not affected by the increase in $\mathrm{K}_{\mathrm{L}} a$.

\section{Role of $K_{L}$ a on growth and enzyme production by Acetobacter tropicalis}

The volumetric oxygen transfer coefficient $\left(\mathrm{K}_{\mathrm{L}} a\right)$ is one of the most important scale up factors in fermentations. $\mathrm{K}_{\mathrm{L}} a$ value affected the growth rate and enzyme activity in $A$. tropicalis for the production of dextransucrase. In the present study, the growth of $A$. tropicalis increased with increase in $\mathrm{K}_{\mathrm{L}} a$ from 0.11 to $0.28 \mathrm{~min}^{-1}$ and thereafter decreased suddenly with further increase in $\mathrm{K}_{\mathrm{L}} a$ (Figure 4). Maximum biomass $(1.41 \mathrm{mg} / \mathrm{ml})$ was obtained at $0.28 \mathrm{~min}^{-1} \mathrm{~K}_{\mathrm{L}} a$. Similar pattern was observed in case of dextransurase production by $A$. tropicalis. Initially enzyme activity increased with increase in $\mathrm{K}_{\mathrm{L}} a$ upto a limit and then decreased (Figure 4). Maximum dextransucrase activity $(15.77 \mathrm{U} / \mathrm{ml})$ was obtained at $0.28 \mathrm{~min}^{-1} \mathrm{~K}_{\mathrm{L}} a$. This exactly coincides with the profile obtained for the growth of A.tropicalis. So, it could be concluded from the above data that higher oxygen transfer rate adversely affect the growth of $A$. tropicalis which in turn result in less dextransucrase production. Maximum production of proteases (15.28 UP/ml) by Staphylococcus aureus mutant RC128 was obtained when the bioreactor was

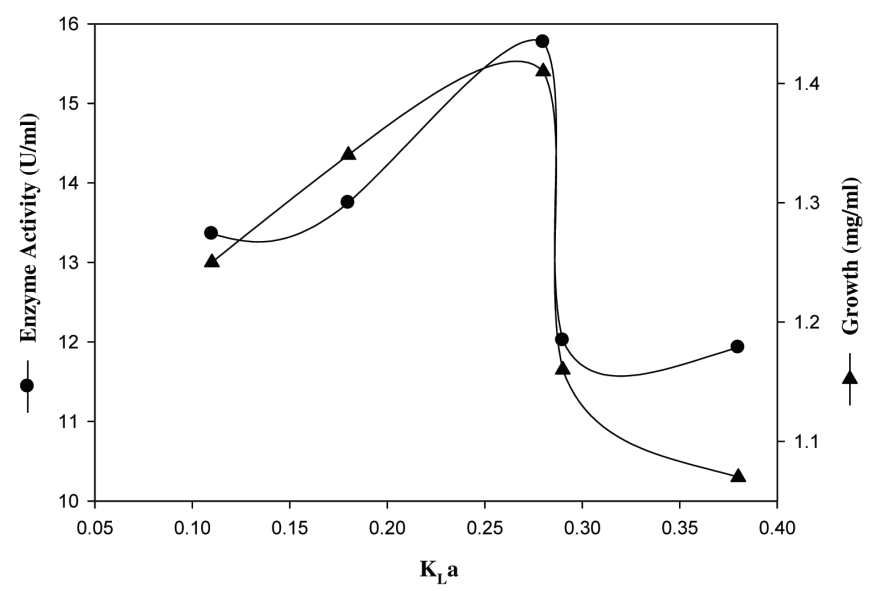

Figure 4 Effect of KLa on growth and dextransucrase production by Acetobacter tropicalis

Table 1 Interactive effect of $\mathrm{K}_{\mathrm{L}} a$ on growth and dextransucrase production by Acetobacter tropicalis

\begin{tabular}{cccccc}
\hline Batch & $\begin{array}{c}\text { Agitation } \\
(\mathrm{rpm})\end{array}$ & $\begin{array}{c}\text { Aeration } \\
(\mathrm{vvm})\end{array}$ & $\begin{array}{c}\text { Enzyme } \\
\text { activity } \\
(\mathrm{U} / \mathrm{ml})\end{array}$ & $\begin{array}{c}\text { Biomass } \\
(\mathrm{mg} / \mathrm{ml})\end{array}$ & $\begin{array}{c}\text { KLa } \\
\left(\mathrm{min}^{-1}\right)\end{array}$ \\
\hline 1. & 150 & 1.0 & 9.83 & 0.86 & --- \\
2. & 300 & 0.5 & 13.35 & 1.25 & 0.11 \\
3. & 300 & 1.0 & 13.75 & 1.34 & 0.18 \\
$\mathbf{4 .}$ & $\mathbf{4 5 0}$ & $\mathbf{0 . 5}$ & $\mathbf{1 5 . 7 7}$ & $\mathbf{1 . 4 1}$ & $\mathbf{0 . 2 8}$ \\
5. & 450 & 1.0 & 12.02 & 1.16 & 0.29 \\
6. & 600 & 0.5 & 11.93 & 1.07 & 0.38 \\
\hline
\end{tabular}

operated at $300 \mathrm{rpm}$ and at 2 vvm with a volumetric oxygen transfer coefficient $\left(\mathrm{K}_{\mathrm{L}} a\right)$ of $175.75 \mathrm{~h}^{-1}$ (37) In case of glucose oxidase production by recombinant Saccharomyces cerevisiae, Kapat et al. [38] concluded that $\mathrm{K}_{\mathrm{L}} a$ alone does not facilitate the specifc production of enzyme. It is the appropriate combination of impeller speed and aeration rate which is more important. Thus, the optimal DO concentration should be considered as a scale up parameter for production process instead of $\mathrm{K}_{\mathrm{L}} a$. The major findings of the dextransucrae production by $A$. tropicalis in a laboratory fermenter have been summarized in Table 1.

\section{Conclusion}

It could be concluded from the present study that oxygen transfer rate plays a vital role in the production of dextransucrase from Acetobacter tropicalis. A. tropicalis growth and dextransucrase production increased with increase in $\mathrm{K}_{\mathrm{L}} a$ upto an optimum limit and then started decreasing with increase in $\mathrm{K}_{\mathrm{L}} a$. The values of $\mathrm{K}_{\mathrm{L}} a$ can be used as a scale up factor for the large scale production of dextransucrase by $A$. tropicalis. Maximum enzyme activity coincided with maximum growth of $A$. tropicalis, which suggests that dextransucrase production was growth associated in nature. The enzyme activity was increased 1.36-fold and fermentation time for dextransucrase production was also lowered. Dextransucrase produced by $A$. tropicalis holds the potential for the commercial production of dextran which has various applications in the biopharmaceutical and food industries.

\section{Acknowledgements}

The authors gratefully acknowledge the financial support by the UGC (University Grant Commission) and Himachal Pradesh University, Summer Hill, Shimla, India, for providing experimental facilities.

\section{Conflicts of Interest}

The authors wish to express that they have no conflict of interest

\section{References}

[1] Brown DE, McAvoy A (1989) A pH controlled fed-batch process for dextransucrase production. J Chem Technol Biotechnol 48:405414.

[2] Dols M, Simeon MR, Willemot RM, Vignon MR, Monsan PF (1997) Structural characterization of the maltose acceptorproducts synthesized by Leuconostoc mesenteroides NRRL B-1299 dextransucrase. Carbohydr Res 305:549-559.

[3] Naessens M, Cerdobbel A, Soetaert W, Vandamme EJ (2005) Leuconostoc dextransucrase and dextran: production, properties and applications. J Chem Technol Biotechnol 80:845-860.

[4] Monchois V, Willemot RM, Monsan P (1999) Glucansucrases: mechanism of action and structure-function relationships. FEMS Microbiol Rev 23:131-151.

[5] Monsan P, Bozonnet S, Albenne C, Joucla G, Willemot RM, et al. (2001) Homopolysaccharides from Lactic Acid Bacteria. Int J Dairy 11:675-685. 
[6.] Sankpal NV, Joshi AP, Sainkar SR, Kulkarni BD (2001) Production of Dextran by Rhizopus sp. Immobilized on Porous Cellulose Support. Process Biochem 37:395-403.

[7] Patel S, Goyal A (2010) Isolation, characterization and mutagenesis of exopolysaccaride synthesizing new strains of lactic acid bacteria. Int J Microbiol 8: 3-4.

[8] PatelS, Majumder A, Goyal A (2012) Potentials of exopolysaccharides from lactic Acid bacteria. Indian J Microbiol 52:3-12.

[9] Purama R, Goyal A (2005) Dextransucrase production by Leuconostoc mesenteroides. Ind J Microbiol 2:89-101.

[10] Koepsell HJ, Tsuchiya HM (1952) Enzymatic synthesis of dextran. J Bacteriol 63:293-295.

[11] Tsuchiya HM, Hellman NN, Koepsell HJ (1953) Factors affecting molecular weight of enzymatically synthesized dextran. J Am Chem Soc 75:757-758.

[12] Paul F, Lopez-Munguia A, Remaud- Simeon M, Pelenc V, Monsan $\mathrm{P}$ (1992) Method for the production of $\alpha-1,2$ oligodextrans using Leuconostoc mesenreroides B-1299. U.S. patent 5,141,858.

[13] Remaud-Simeon M, Lopez-Munguia A, Pelenc V, Paul F, Monsan P (1994) Production and use of glucosyltransferases from Leuconostoc mesenteroides NRRL B-1299 for the synthesis of oligosaccharides containing alpha-(1-->2) linkages. Appl Biochem Biotechnol 44:101-107.

[14] Valette P, Pelenc V, Djouzi Z, Andrieux C, Paul F, et al. (1993) Bioavailability of new synthesized glucooligosaccharides in the intestinal tract of gnotobiotic rats. J Food Sci 62:121-127.

[15] Quirasco M, Lopez-Munguia A, Pelenc V, Remaud M, Paul F, et al. (1995) Enzymatic production of glucooligosaccharides containing alpha-(1-->2) osidic bonds. Potential application in nutrition. Ann N Y Acad Sci 750:317-320.

[16] Demuth B, Jördening HJ, Buchholz K (1999) Modelling of oligosaccharide synthesis by dextransucrase. Biotechnol Bioeng 62:583-592.

[17] Richard G, Yu S, Monsan P, Remaud-Simeon M, Morel S (2005) A novel family of glucosyl 1,5-anhydro-d-fructose derivatives synthesised by transglucosylation with dextransucrase from Leuconostoc mesenteroides NRRL B-512F. Carbohydr Res 340:395401.

[18] Lopretti M, Martinez E, Torres L, Santos M, Rodrigues AE (1999) Influence of the nitrogen/carbon ratio and complementary sugars on dextransucrase production by Leuconostoc mesenteroides NRRL B512(f). Process Biochem 34:879-884.

[19] Santos M (2000) Production of dextran and fructose from sucrose using Leuconostoc mesenteroides. PhD thesis. Univ Porto.

[20] Santos M, Teixeira J, Rodrigues AE (2000) Production of dextransucrase, dextran and fructose from sucrose using Leuconostoc mesenteroides NRRL B512(f). Biochem Eng J 4:177188.

[21] Coelho M, Azevedo D, Teixeira J, Rodrigues AE (2002) Dextran and fructose separation on a SMB continuous chromatographic unit. Biochem Eng J 12(3):215-221.

[22] Schnieder M, Guillot C and Ayerbe A (1984) UK Patent 2079292 B.

[23] Lazic ML, Veljkovic VB, Vucetic VB, Vrvic MM (1993) Effect of pH on dextran production by Leuconostoc mesenteroides. Enzyme Microb Technol 15:334-338.

[24] De Man JC, Rogosa M, Sharpe ME (1960) Medium for the cultivation of lactobacilli. J Appl Microbiol 23:130-135.

[25] Miller GL (1959) Use of dinitrosalicylic acid reagent of determination of reducing sugar. Anal Chem 31:426-428.

[26] Cortezi M, Monti R, Contiero (2005) Temperature effect on dextransucrase production by Leuconostoc mesenteroides FT 045 B isolated from alcohol and sugar mill plant. Afr J Biotechnol 4:279285.
[27] Monsan P, López A (1981) Production of dextran by free and immobilized dextransucrase. Biotechnol Bioeng 23:2027-2037.

[28] Landon RS, Webb C (1990) Separating Enzyme (dextransucrase) production and product (Dextran) Synthesis within a traditional fermentation process. Process Biochem 25:19-23.

[29] Shukla S, Goyal A (2012) Development of Efficient Fermentation Process at Bioreactor Level by Taguchi's Orthogonal Array Methodology for Enhanced Dextransucrase Production from Weissella confusa Cab3. Adv Microbiol 2:277-283.

[30] Barker PE, Ajongwhen NJ (1991) The production of the enzyme dextransucrase using nonaerated fermentation techniques. Biotechnol Bioeng 37:703-707.

[31] Michelena GL, Martinez A, Bill A, Carrera E, Valencia R (2003) Scale up of Dextransucrase Production by Leuconostoc mesenteroides in Fed Batch Fermentation. Braz Arch Biol Technol 46(3):455-459.

[32] Mel M, Karim MIA, Salleh HM (2010) The Evaluation of $K_{L} \mathrm{a}$ values for Recombinant Escherichia coli Fermentation Producing ß-glucuronidase enzyme. J Appl Sci 10:325-330.

[33] Songpim M, Vaithanomsat P, Chuntranuluck S (2010) Optimization of Pectate Lyase Production from Paenibacillus polymyxa N10 using Response Surface Methodology. Open Bio J 3:1-7.

[34] Sachidanandham R, Ranjit Kumar IA, Krishnan MRV, Jayaraman K (1999) Mathematical model based estimation of volumetric oxygen transfer coeffcient(s) in the production of proteolytic enzymes in Bacillus amyloliquefaciens. Bioprocess Eng 21:319-322.

[35] Belo M, Mota M (1998) Batch and fed batch cultures of E. coli TB1 at different oxygen transfer rates. Bioprocess Eng 18:451-455.

[36] Pham PL, Strehaiano P, Taillandier P (1997) Effect of aeration on xylanase production by Bacillus sp. I-1018. Bioprocess Eng 18:4143.

[37] Ducros E, Ferrari M, Pellegrino M, Raspanti C, Bogni C (2009) Effect of aeration and agitation on the protease production by Staphylococcus aureus mutant RC128 in a stirred tank bioreactor. Bioprocess Biosyst Eng 32:143-148.

[38] Kapat A, Jung JK, Park YH (2001) Enhancement of glucose oxidase production in batch cultivation of recombinant Saccharomyces cerevisiae: optimization of oxygen transfer condition. J Appl Microbiol. 90:216-222. 